\title{
Antibacterial and Antifungal Activity of Medicinal Orchids Growing in Nepal
}

\author{
Ramesh Marasini* and Susan Joshi \\ Central Department of Chemistry, Tribhuvan University, Kirtipur, Kathmandu, Nepal \\ E-mail: nature.ramesh@yahoo.com, susanjoshi68@gmail.com
}

\begin{abstract}
Antibacterial activities of different extracts of epiphytic orchids were tested against 5 species of bacteria and antifungal activities were tested against 3 species of fungi. All orchid extracts showed good bacterial Zone of Inhibition (ZOI) against Staphylococcus aureus. The crude extracts of Pholidota imbricata and Coelogyne cristata were shown highest activity against Vibrio cholerae and Staphylococcus aureus respectively. The MIC and MBC value of the extracts of Pholidota imbricata and Coelogyne cristata were found to be $62.5 \mathrm{mg} / \mathrm{ml}, 31.25 \mathrm{mg} / \mathrm{ml}$ and $125 \mathrm{mg} / \mathrm{ml}, 250 \mathrm{mg} / \mathrm{ml}$ against Vibrio cholerae and Staphylococcus aureus respectively. Only Pholidota imbricata and Pholidota articulata extracts were shown fairly good activity but all others extracts were shown very less activity or even failed to show any activity against fungal organisms.
\end{abstract}

Keywords: Epiphytic orchids, Zone of Inhibition, Antibacterial, Antifungal

\section{Introduction}

Out of many medicinal aromatic plants, many orchids have been used as traditional system of medicines. Orchidaceae is one of largest family among angiosperms with more than 30,000 species of 750 genera in the world. In Nepal nearly 388 orchid's species with 99 genera are reported ${ }^{1}$ which are famous by the name of "Sunakhari", "Sungava", "Chandigava". In Nepal, 30 species of orchid belonging to 23 genera are used for medicinal purpose ${ }^{2}$. Orchids are widely known for economic importance but less for their medicinal values. Recently there has been tremendous progress in medicinal plant research; however orchids have not been explored fully for their medicinal applications and pharmacological studies $^{3}$.

Historically the term 'orchid' was coined by Theophrastus as anatomy of the plants resemble with testis. Greek word orchid literally means testicles. This may account for the use of orchids as aphrodisiacs in ancient civilization. When we study the history of the ancient alternative system of medicine Ayurveda and Traditional Chinese Medicine (TCM) are one the forefront ${ }^{4}$. Asthavargha, is important ingredient of various classical Ayurvedic formulations like Chavyanprasa. Out of eight constituent of Arthavargha, four have been reported to be orchids as 'Jivaka' (Malaxis muscifera), 'Rishbhaka' (M. acuminate), 'Riddhi' (Habenaria intermedia), and 'Vriddhi' (H. edgeworthii $)^{5}$.

The medicinal orchids belong mainly to the genera Dendrobiun, Coelogyne, Cymbidium, Cypipedium, Eria, Anoectochilus, Calanthe, Bulbophyllum, Dactylorhiza, Habenaria, Nevilia, Pholidota, Galeola, and Gastrodia. A number of alkaloids have been extracted from orchids, such as chysine, drobine, dendronine, grandifolin and crepidine ${ }^{6}$. For example, the pods of Vanilla plantifolia are used for the extraction of vanillin, widely used as flavoring agent ${ }^{7}$.

A wide range of chemical compounds are presented including alkaloids, bibenzyle derivatives, flavonoides, phenanthrenes and terpenoides which have been isolated from various orchids from different

\section{Corresponding author}


parts of the world. Extracts and metabolites of these plants, particularly those from flowers, steam and leaves, possesses useful pharmacological activities. Particular attention has been given to diuretic, antirheumatic, anti- inflammatory, anti-carcinogenic, hypoglycemic activities, anti-microbial, anticonvulsive, relaxation, neuroprotective and anti- virus activities ${ }^{3}$.

\section{Experimental Method}

\section{Collection of Plant Materials}

The plant materials chosen for study were different medicinal epiphytic orchids. All the orchids were collected from different parts of the Nepal from April - November 2010 to conduct this research work.

\section{Preparations of extracts}

The different parts of epiphytic orchids were cleaned, chopped in small pieces and dried in a shade. They were then grinded in grinder into the powder form. The powdered plant materials were cold percolated using ethanol in the ratio of 1:4 (W/V). The ethanol extract was concentrated in Rota-Vapour under reduced pressure and was taken as ethanol extract.

\section{Preparation of working solution}

$5 \%$ working solution was prepared by transferring $5 \mathrm{mg}$ of each extract to sterile vial aseptically containing $1 \mathrm{ml}$ DMSO solvent which was then capped sealed and stored in refrigerator until use.

\section{Microorganisms used}

Present study includes 5 different species of bacteria including both gram positive and gram negative and 3 different species of fungi. Gram Positive Bacteria: Staphylococcus aureus and Bacillus subtilis. Gram Negative Bacteria: Vibrio cholerae, Escherichia coli and Klebsiella pneumonia.

The fungal organisms used for the present study were namely Candida albicans, Rhyzopus stolonifer and Mucor spps.

\section{Antibacterial activity}

Inhibition of bacterial growth was tested by agar well diffusion method. Already prepared Sterile Muller Hinton Agar (MHA) plates were taken and dried in an incubator at $37^{\circ} \mathrm{C}$ for 30 minutes. The standard working inoculums of five different organisms were also taken. A sterile cotton swab was dipped into the standard working inoculums (equivalent with McFarland turbidity standard, cell density $1.5 \times 108 \mathrm{CFU} / \mathrm{ml}$ ) of a organism tube. The swab was then pressed to the wall of tube above liquid with rotating to remove excess inoculums ${ }^{60}$. The swab was streaked all over the MHA plates in the angle of $60^{\circ} \mathrm{c}$ for three times with rotating the plates. All the inoculated plates were left to dry at room temperature for about 10 minutes with closed lid.

The wells were made in the incubated media plates with the help of sterile cork borer $(6 \mathrm{~mm})$ and labeled properly. Then $50 \mu 1$ of the working solution of plant extract were loaded into the respective wells with the help of micropipette. The solvent itself was tested for its activity as a control at the same time in the separate well. The plates were then left for half an hour with the lid closed so that plant extract diffused to the media. The plates were incubated overnight at $37^{\circ} \mathrm{C}$. The plates were then observed for the zone of inhibition (ZOI) produced by the anti- bacterial activity of different plant extracts. At the same time ZOI of different organism by different samples were measured with the help of the ruler for the estimation of potency of anti- bacterial substance and tabulated.

From the result of ZOI, the plant extracts which had shown excellent antimicrobial activity against tested bacterial strains were chosen for determination of MIC up to maximum dilution by tube dilution method as per the guidelines given by CLSI, $2010^{7}$. 


\section{Antifungal activity}

Inhibition of fungal growth was also tested by agar well diffusion method. Sterile potato dextrose agar (PDA) plates were prepared. Before using the plates, they were dried in hot air oven at $40^{\circ} \mathrm{C}$ for 5 minutes to remove excess of moisture from the surface of the media. Sterile cotton swab was dipped into the prepared inoculums and excess of inoculums were removed by pressing and rotating against the upper inside wall of the tube above liquid level and then swabbed carefully all over the plates. The plates were rotated through an angle of $60^{\circ}$ after each swabbing. Finally the swab was passed round the edges of the agar surface. The inoculated plates were left to dry for few minutes at room temperature with the lid closed.

The wells were made in PDA plates. $50 \mu$ of the working solution of plant extracts were loaded and the solvent itself was tested for its activity as a control at the same time in the separate well. The plates were then left for half an hour with the lid closed so that plant extract diffused to the media. The plates were incubated for the seven days at $27^{\circ} \mathrm{C}$. The plates were then observed for the zone of inhibition (ZOI) produced by the antifungal activity of different plant extracts.

\section{Result and Discussion}

The results of antibacterial activity are presented in Table 1 . No zone of inhibition was observed in control region. Only Coelogyne stricta (leaf) and Dendrobium amoeneum were shown good activity against Klebsiella pneumonae but Pholidota articulata and P. imbricata were shown good activity against Escherichia coli. Eria spicata, Bulbophyllum affine, Vanda cristata and Rynchostylis retusa were shown weak activity against all bacteria. Dendrobium nobile showed good inhibition against Staphylococcus aureus but weak against all others bacteria. All plants extract showed very good inhibition against Staphylococcus aureus. Pholidota imbricata and Coelogyne cristata were shown highest inhibition against Vibrio cholera and Staphylococcus aureus respectively.

Table 1: Result of antibacterial activity of 5\% solution of different extracts of Orchids

\begin{tabular}{|c|c|c|c|c|c|}
\hline Plant Samples & Test Organisms & $\begin{array}{l}\mathrm{ZOI} \\
(\mathrm{mm})\end{array}$ & Plant Samples & Test Organisms & $\begin{array}{l}\mathrm{ZOI} \\
(\mathrm{mm})\end{array}$ \\
\hline 1.Eria spicata & $\begin{array}{l}\text { Vibrio cholerae } \\
\text { Staphylococus aureus } \\
\text { Bacillus subtilis } \\
\text { Escherichia coli } \\
\text { Klebsiella pneumoniae }\end{array}$ & $\begin{array}{l}- \\
8 \\
- \\
- \\
8\end{array}$ & $\begin{array}{l}\text { 7.Pholidota } \\
\text { imbricata }\end{array}$ & $\begin{array}{l}\text { Vibrio cholerae } \\
\text { Staphylococus aureus } \\
\text { Bacillus subtilis } \\
\text { Escherichia coli } \\
\text { Klebsiella pneumonia }\end{array}$ & $\begin{array}{c}14 \\
13 \\
10 \\
10 \\
8 \\
\end{array}$ \\
\hline $\begin{array}{l}\text { 2.Bulbophyllum } \\
\text { affine }\end{array}$ & $\begin{array}{l}\text { Vibrio cholerae } \\
\text { Staphylococus aureus } \\
\text { Bacillus subtilis } \\
\text { Escherichia coli } \\
\text { Klebsiella pneumoniae }\end{array}$ & $\begin{array}{l}- \\
10 \\
- \\
- \\
-\end{array}$ & $\begin{array}{l}\text { 8. P. } \\
\text { articulata }\end{array}$ & $\begin{array}{l}\text { Vibrio cholerae } \\
\text { Staphylococus aureus } \\
\text { Bacillus subtilis } \\
\text { Escherichia coli } \\
\text { Klebsiella pneumonia }\end{array}$ & $\begin{array}{c}- \\
12 \\
10 \\
8 \\
9\end{array}$ \\
\hline 3. Vanda cristata & $\begin{array}{l}\text { Vibrio cholerae } \\
\text { Staphylococus aureus } \\
\text { Bacillus subtilis } \\
\text { Escherichia coli } \\
\text { Klebsiella pneumoniae }\end{array}$ & $\begin{array}{l}- \\
8 \\
- \\
- \\
8\end{array}$ & $\begin{array}{l}\text { 9. Coelogyne } \\
\text { cristata }\end{array}$ & $\begin{array}{l}\text { Vibrio cholerae } \\
\text { Staphylococus aureus } \\
\text { Bacillus subtilis } \\
\text { Escherichia coli } \\
\text { Klebsiella pneumonia }\end{array}$ & $\begin{array}{c}- \\
14 \\
8 \\
10 \\
8\end{array}$ \\
\hline $\begin{array}{l}\text { 4.Rynchostylis } \\
\text { retusa }\end{array}$ & $\begin{array}{l}\text { Vibrio cholerae } \\
\text { Staphylococus aureus } \\
\text { Bacillus subtilis } \\
\text { Escherichia coli } \\
\text { Klebsiella pneumoniae }\end{array}$ & $\begin{array}{l}- \\
8 \\
- \\
- \\
9\end{array}$ & $\begin{array}{l}\text { 10. Coelogyne } \\
\text { stricta }\end{array}$ & $\begin{array}{l}\text { Vibrio cholerae } \\
\text { Staphylococus aureus } \\
\text { Bacillus subtilis } \\
\text { Escherichia coli } \\
\text { Klebsiella pneumonia }\end{array}$ & $\begin{array}{l}10 \\
12 \\
10 \\
8 \\
8\end{array}$ \\
\hline
\end{tabular}


J. Nepal Chem. Soc., vol. 29, 2012

\begin{tabular}{|l|l|c|l|l|c|}
\hline & Vibrio cholerae & 8 & & Vibrio cholerae & 10 \\
5.Dendrobium & Staphylococus aureus & 12 & & Staphylococus aureus & 12 \\
nobile & Bacillus subtilis & 8 & 11. Coelogyne & Bacillus subtilis & 10 \\
& Escherichia coli & 8 & stricta (leaf) & Escherichia coli & 8 \\
& Klebsiella pneumoniae & 8 & & Klebsiella pneumonia & 10 \\
\hline \multirow{5}{*}{ 6.Dendrobium } & Vibrio cholere & 11 & & \\
amoneum & Staphylococus aureus & 12 & & \\
& Bacillus subtilis & 8 & & \\
& Escherichia coli & 8 & & & \\
& Klebsiella pneumoniae & 12 & &
\end{tabular}

N.B.: ZOI more than $12 \mathrm{~mm}$ was considered as most active, from 9-11 mm moderately active and from 7$8 \mathrm{~mm}$ weakly active ${ }^{8}$

After evaluating the ZOI values of various extracts, two extracts with higest ZOI value were taken for MIC test by two fold serial dilution method. MIC of extract of Coelogyne cristata was tested against Staphylococcus aureus and that of Pholidota imbricata against Vibrio cholerae. Table 2 shows the value of MIC and MBC of extracts. The MIC of Coelogyne cristata against Staphylococcus aureus was observed at $31.25 \mathrm{mg} / \mathrm{ml}$ and that of Pholidota imbricata against Vibrio cholerae was observed at 62.5 $\mathrm{mg} / \mathrm{ml}$. The MBC values of the extracts of Pholidota imbricata against Vibrio cholerae and Coelogyne cristata against Staphylococcus aureus were observed $125 \mathrm{mg} / \mathrm{ml}$ and $250 \mathrm{mg} / \mathrm{ml}$ respectively.

Table 2: MIC and MBC value determination of extracts

\begin{tabular}{|l|l|l|l|l|l|l|}
\hline \multirow{2}{*}{ Plant Sample } & \multirow{2}{*}{ Organism Used } & \multicolumn{5}{|c|}{ Dilution of extracts (mg/ml) } \\
\cline { 3 - 8 } & Vibrio cholerae & $\begin{array}{l}250 \\
\text { Nil } \\
\text { Coelogyne cristata }\end{array}$ & Nil & Nil & $\begin{array}{l}\text { Nil } \\
¥\end{array}$ & $\sqrt{ }$ \\
\hline Pholidota imbricata & Staphylococcus aureus & Nil & $\begin{array}{l}\text { Nil } \\
\text { N }\end{array}$ & $\begin{array}{l}\text { Nil } \\
¥\end{array}$ & $\sqrt{ }$ & $\sqrt{ }$ \\
\hline
\end{tabular}

N.B: Nil $=$ No growth of bacteria, $\sqrt{ }=$ Growth of bacteria, $¥=\mathrm{MIC},=\mathrm{MBC}$
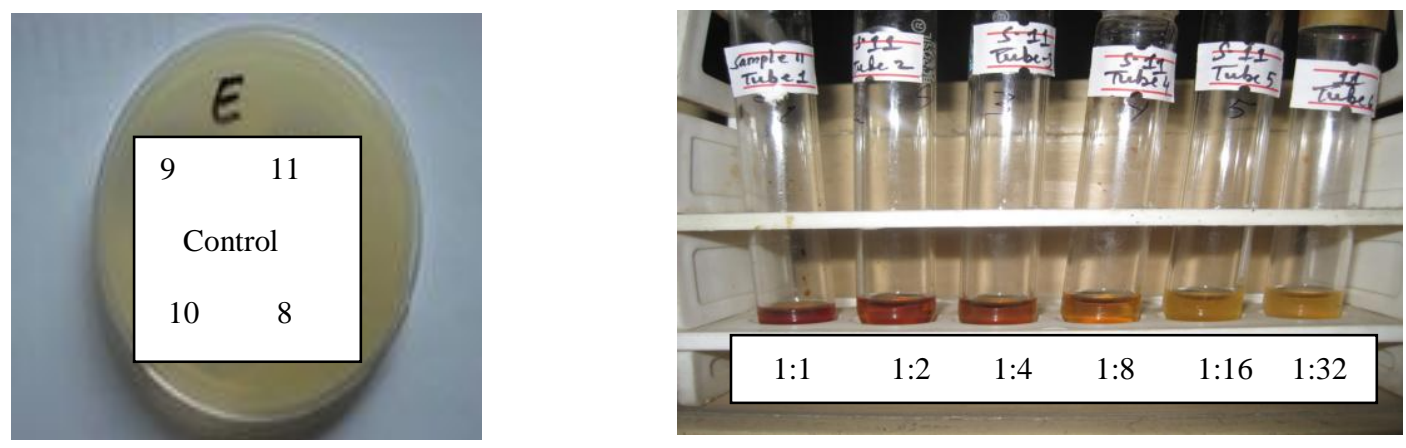

Figure 1 (left): ZOI of 5\% of extracts of sample 8, 9, 10 \&11 against Staphylococcus. Figure 2(right): MIC of extract of Pholidota articulata against Staphylococcus

Table 3 shows the result of antifungal activities of different orchid extracts. Coelogyne stricta (Pseudobulb), Coelogyne stricta (leaf) and Dendrobium amoeneum were shown no activity while Pholidota imbricata and $P$. articulata extracts were shown good activity against fungal organisms. Rest of the extracts showed moderate or even very weak activity against selected fungal pathogens. 
Table 3: Result of antifungal activity of 5\% solution of different extracts of Orchids

\begin{tabular}{|c|c|c|c|c|c|}
\hline Plant Samples & Test Organisms & $\begin{array}{l}\mathrm{ZOI} \\
(\mathrm{mm})\end{array}$ & $\begin{array}{l}\text { Plant } \\
\text { Samples }\end{array}$ & Test Organisms & $\begin{array}{l}\text { ZOI } \\
(\mathrm{mm})\end{array}$ \\
\hline Eria spicata & $\begin{array}{l}\text { Candida albicans } \\
\text { Rhyzopus stolonifer } \\
\text { Mucor spps }\end{array}$ & $\begin{array}{l}8 \\
8 \\
8\end{array}$ & $\begin{array}{l}\text { Pholidota } \\
\text { imbricata }\end{array}$ & $\begin{array}{l}\text { Candida albicans } \\
\text { Rhyzopus stolonifer } \\
\text { Mucor spps }\end{array}$ & $\begin{array}{c}10 \\
10 \\
8\end{array}$ \\
\hline $\begin{array}{l}\text { Bulbophyllum } \\
\text { affine }\end{array}$ & $\begin{array}{l}\text { Candida albicans } \\
\text { Rhyzopus stolonifer } \\
\text { Mucor spps }\end{array}$ & $\begin{array}{l}8 \\
8 \\
-\end{array}$ & $\begin{array}{l}P . \\
\text { articulata }\end{array}$ & $\begin{array}{l}\text { Candida albicans } \\
\text { Rhyzopus stolonifer } \\
\text { Mucor spps }\end{array}$ & $\begin{array}{c}10 \\
8 \\
8\end{array}$ \\
\hline Vanda cristata & $\begin{array}{l}\text { Candida albicans } \\
\text { Rhyzopus stolonifer } \\
\text { Mucor spps }\end{array}$ & $\begin{array}{l}8 \\
- \\
8\end{array}$ & $\begin{array}{l}\text { Coelogyne } \\
\text { cristata }\end{array}$ & $\begin{array}{l}\text { Candida albicans } \\
\text { Rhyzopus stolonifer } \\
\text { Mucor spps }\end{array}$ & $\begin{array}{l}8 \\
- \\
8\end{array}$ \\
\hline $\begin{array}{l}\text { Rynchostylis } \\
\text { retusa }\end{array}$ & $\begin{array}{l}\text { Candida albicans } \\
\text { Rhyzopus stolonifer } \\
\text { Mucor spps }\end{array}$ & $\begin{array}{l}8 \\
8 \\
-\end{array}$ & $\begin{array}{l}\text { Coelogyne } \\
\text { stricta }\end{array}$ & $\begin{array}{l}\text { Candida albicans } \\
\text { Rhyzopus stolonifer } \\
\text { Mucor spps }\end{array}$ & $\begin{array}{l}- \\
- \\
-\end{array}$ \\
\hline $\begin{array}{l}\text { Dendrobium } \\
\text { nobile }\end{array}$ & $\begin{array}{l}\text { Candida albicans } \\
\text { Rhyzopus stolonifer } \\
\text { Mucor spps }\end{array}$ & $\begin{array}{l}8 \\
8 \\
8\end{array}$ & $\begin{array}{l}\text { Coelogyne } \\
\text { stricta } \\
\text { (leaf) }\end{array}$ & $\begin{array}{l}\text { Candida albicans } \\
\text { Rhyzopus stolonifer } \\
\text { Mucor spps }\end{array}$ & - \\
\hline $\begin{array}{l}\text { Dendrobium } \\
\text { amoenum }\end{array}$ & $\begin{array}{l}\text { Candida albicans } \\
\text { Rhyzopus stolonifer } \\
\text { Mucor spps }\end{array}$ & $\begin{array}{l}- \\
- \\
-\end{array}$ & & & \\
\hline
\end{tabular}

\section{Conclusion}

Result showed that different extracts of epiphytic orchids have good antibacterial and antifungal properties. Antibacterial activities shown by Coelogyne cristata, Pholidota articulata and P. imbricata extracts were most active then others extracts. Pholidota imbricata and $P$. articulata extracts were shown intermediate activity but all others extracts were shown very less activity or even failed to show activity against all different five fungal organisms. This results form a good basis for further pharmacological investigation on medicinal orchids.

\section{Acknowledgement}

Authors would like to thank Associate Prof. Dr. Dwij Raj Bhatta, Central Department Microbiology, Tribhuvan University, Kathmandu for providing necessary laboratory facilities. Mr. Anil Sharma, Mr. Prakash Bhattrai and Ms. Rita Chettri, Central Department of Botany, Tribhuvan University, Kathmandu are acknowledged for their help during field visit to collect orchids and their identification. 


\section{References}

1. Acharya K. P. Orchid species richness along a Himalayan elevation gradient. Department of Biology, Faculty of Mathematics and Natural Sciences, University of Bergen, Bergen (M. S. Thesis), 2008, pp 3-9.

2. Shakya L. R. Revision of the genus Oberonia Lindl. (Orchidaceae) in the Himalayas. Ph. D. Dissertation, Central Department of Botany, Tribhuvan University, Kirtipur, Kathmandu, Nepal, 1999, pp. 10- 30.

3. Rosa M. P. G. Journal of Medicinal Plants Research, 2010, 4 (8), pp. 592- 638.

4. Vaidya B., M. Shrestha and N. Joshee. Report on Nepalese Orchid species with medicinal properties. In The Himalayan plants, can they save us? Proceeding of Nepal- Japan joint symposium on conservation and utilization of Himalayan medicinal resources (Eds. $\mathrm{T}$. Watanabe, A. Tanako, M. S. Bista and H. K. Saiju), Society for the Conservation and development of Himalayan Medicinal Resources (SCDHMR), Japan, 2000, pp. 146-152.

5. Sharma A. Diversity and distribution pattern of epiphytic orchids along Bhote Koshi gorge (Upper Tamakoshi Valley), Dolakha, Central Nepal. M. Sc. Dissertation, Central Department of Botany, T. U., Nepal, 2010, pp. 3-6.

6. Singh, A. and Duggal, S. Ethnobotanical Leaflets, 2009, 13, pp. 351- 63.

7. Clinical Laboratory Standard Institute, Performance Standard for antimicrobial susceptibility testing, M100-520, 2010, 30 (15).

8. Nostro A., Germano M. P., D’ Angelo V., Marino A. and Cannatelli M. A. Letter in Applied Microbiology, 2000, 30, pp.379-384. 